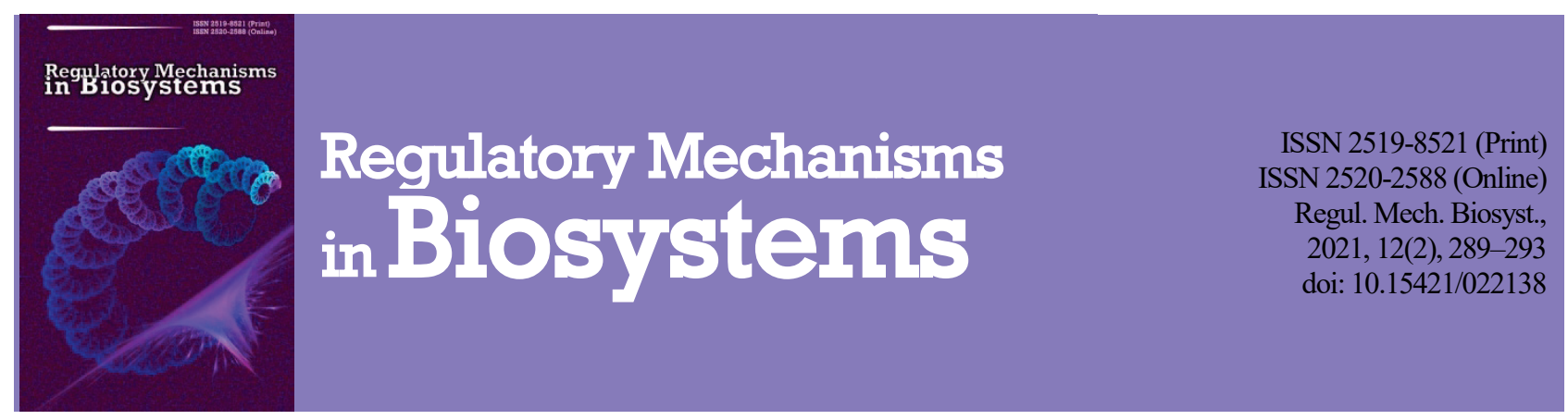

\title{
Efficacy of manganese pantothenate and lysinate chelates for prevention of perosis in broiler chickens
}

\author{
V. S. Sakara, A. Y. Melnyk, V. V. Sakhniuk, N. V. Vovkotrub, M. M. Fedorchenko, Y. O. Balatskiy, L. V. Bondarenko \\ Bila Tserkva National Agrarian University, Bila Tserkva, Ukraine
}

Article info

Received 16.03.2021

Received in revised form 21.04.2021

Accepted 22.04.2021

Sakara, V. S., Melnyk, A. Y., Sakhniuk, V. V., Vovkotrub, N. V., Fedorchenko, M. M., Balatskiy, Y. O., \& Bondarenko, L. V. (2021). Efficacy of manganese pantothenate and lysinate chelates for prevention of perosis in broiler chickens. Regulatory Mechanisms in Biosystems, 12(2), 289-293. doi:10.15421/022138

Bila Tserkva National Agrarian University,

Soborna sq., $8 / 1$

Bila Tserkva, 09117, Ukraine

Tel.: +38-097-034-01-15.

E-mail:

vitalii.sakara@btsau.edu.ua

Perosis is a common metabolic disease of industrial birds, especially broiler chickens. It leads to a violation of the balance of biotic substances in the body of chickens, which is clinically manifested by the curvature of the limbs, reduced mobility, and, consequently, reduced profitability of meat production. Prevention of perosis is possible provided that chickens receive a sufficient amount of manganese in a biologically available form. Studies were conducted to determine the efficiency of use of manganese chelates (pantothenate and lysinate) for prevention of perosis in broiler chickens. Efficacy was confirmed by examining changes in the clinical state, indicators of protein and mineral metabolism, as well as meat productivity of birds. For the experiment, broiler chickens of the Cobb-500 cross were taken at the age of 14 days. The birds of the control group received a standard diet, and the chickens from two experimental groups additionally received manganese pantothenate and lysinate with water during the critical period for the development of perosis - 14-28 days old. After 14 days of administration of manganese pantothenate and lysinate, the weight of the experimental birds at the age of 28 days was greater by $133.6 \mathrm{~g}(+11.0 \%)$ and $142.2 \mathrm{~g}(+11.7 \%)$, respectively, in comparison with poultry of the control group. Additional provision of manganese pantothenate and lysinate to chickens of the experimental groups contributed to an increase in the blood serum total protein concentration by $11.0 \%$ and $12.8 \%$, albumin - by $10.1 \%$ and $8.2 \%$, magnesium - by $8.1 \%$ and $9.0 \%$ and manganese - by $29.6 \%$ and $26.9 \%$, respectively, compared with indicies of the control group birds. The use of manganese chelates in the form of pantothenate $(0.2 \mathrm{~mL} / \mathrm{L}$ of water) and a lysinate $(0.5 \mathrm{~mL} / \mathrm{L})$ during the 14-28th days of broiler chickens' rearing provides $100 \%$ prevention of perosis. This reduces the death of broiler chickens, increases body weight, and, as a result, significantly increases the profitability of meat production.

Keywords: protein metabolism; mineral metabolism; amino acids; trace elements; poultry.

\section{Introduction}

Due to the high growth rate of modern crossbreed meat poultry and insufficient mineral supply, there are more frequent cases of limb pathology in broiler chickens (Dinev, 2012). Nutrient requirements for chicks can vary by sex, rearing phase, and cross-breeding (Pacheco et al., 2017). Trace elements such as zinc and manganese are essential for the physiological processes of bone tissue development of all animals (Richards et al., 2010; Bomko et al., 2018). Manganese (Mn) is an important micronutrient in bird feeding, which is necessary for the prevention of perosis, improving the bearing and strength of the eggshell (Aschner \& Aschner, 2005; Tufarelli \& Laudadio, 2017). It is necessary for normal immune function, regulation of blood sugar and cellular energy, reproduction, digestion, bone growth, and helps protect against free radicals (Liu et al., 2015). Also, a no less important element for poultry is zinc. It is a component of about 300 enzymes and acts as their activator (lecithinase, arginase, some peptidases) (Britanico et al., 2012). Zinc enhances the effect on mineralization, formation and increase in bone mass and synthesis of keratin and collagen proteins that form the feather cover (Pacheco et al., 2017).

Perosis in broiler chickens occurs due to the low content of the manganese in the diet (Liu et al., 2015) and manifests itself at the age of 14 28 days (Dinev, 2012). This trace element deficiency in the diet of chickens can occur not only when it is insufficiently contained in the feed, but also when the feed production technology is violated (Oviedo-Rondón et al., 2006). Although the problem of perosis and possible ways of solving it are well known to scientists, this disease remains an important focus of scientific work of scientists from different countries of the world: the USA (Lilburn, 2021), Brazil (Noetzold et al., 2020; Santiago et al., 2020), China (Wang et al., 2020; Zhang et al., 2020), Poland (Matuszewski et al., 2020). To prevent trace elements' deficiencies, it is customary to add them to the diet in the form of inorganic salts (Stanaćev et al., 2014). The assimilability of these inorganic forms varies within 5-20\%, while organic (chelate compounds) - 80-90\% (Britanico et al., 2012). Organic trace elements in the chelated forms have several advantages: they are stable in the gastrointestinal tract and are protected from the formation of complexes with other food components that inhibit their absorption (Vieira, 2008). Also, the addition of minerals in the chelated form improves their transport and absorption in the birds' intestines (RamosVidales, 2019). Despite the high level of bioavailability in comparison with non-organic trace elements, their chelated forms are much more expensive, therefore it is not economically feasible to replace them by $100 \%$ in the diet of chickens on small farms.

Each private broiler chicken farm has its program for infectious and non-infectious poultry diseases prevention. But farms do not always have the opportunity to manufacture or purchase compound feed with a new composition of trace elements. Also, it is difficult to add and effectively mix the trace element supplements using low quality equipment (OviedoRondón et al., 2006). Therefore, it remains relevant for small poultry farms to add critical minerals with water using the dosing pumps, which allows them to be accurately dosed without significant expenditures of time, labour, and funds (Whaley, 2004).

The study aimed to determine the effectiveness of manganese pantothenate and lysinate for perosis prevention, determining changes in the clinical state, biochemical blood parameters, and meat productivity of broiler chickens. 


\section{Materials and methods}

The study was conducted in 2020 at the Training and Production Centre poultry farm, and on the basis of the Scientific Research Institute of Internal Diseases of Animals of the Bila Tserkva National Agrarian University. The research protocol of the current study was approved by the Ethics Committee of the Bila Tserkva National Agrarian University (Approval number: 20.08.2019, No. 7).

Before the experiment, we selected 300 chickens aged 1-day Cobb500 cross for subsequent formation of control and experimental groups. Before they reached the age of 14 days, we conducted a daily clinical examination of these chickens. For the experiment, three groups (according to the principle of analogues, from the one batch) of 14-day-old healthy broiler chickens were selected - a control group and two experimental ones $(n=50)$. This age period was chosen due to the intensity of the bone and cartilaginous tissue development; chickens 14-28 days old are the most vulnerable to perosis (Knowles, 2008).

At the beginning of the experiment, broiler chickens were kept in coops stocked with a density of $14 \mathrm{birds} / \mathrm{m}^{2}$, on a bed of straw. The air temperature for chickens on the 14th day of rearing was $27.5^{\circ} \mathrm{C}$, on the 21 st day $-25^{\circ} \mathrm{C}$, and on the 28 th day $-23^{\circ} \mathrm{C}$ (with a relative humidity of
$50 \%$ during the entire period). The light cycle for the birds was 16 hours of light and 8 hours of darkness. Throughout the experiment, the chickens had free access to food and water. By the beginning of the experiment, the chickens were vaccinated against Newcastle and Gumboro diseases, and infectious bronchitis according to the preventive measures program developed at the farm. On the 20th day of life, they were re-vaccinated against Newcastle disease.

For the experiment, we chose the manganese chelates - pantothenate and lysinate. For the first experimental group we used a vitamin-amino acid (pantetonate) manganese supplement - based on the glycine and pantothenic acid (at a dose of $0.2 \mathrm{~mL} / \mathrm{L}$ of water); for the second experimental group - based on the lysine, at a dose of $0.5 \mathrm{~mL} / \mathrm{L}$ of water (TS U 24.130931207-011-2007, Private enterprise "Kronos-Agro", Ukraine). Chelated manganese was fed to the experimental broiler chickens at the age of 14-28 days old (Table 1).

Feeding of the broiler chickens was carried out according to the technological chart with the compound feed of the farm's production: the starter (14-21th days), the grower (22-35th days), and the finisher (from the 36th day until slaughter). The feed compositions were made based on the corn, soybeans, and sunflower meal from the plant materials of local cultivation (Table 2).

\section{Table 1}

Experiment scheme for broiler chickens of control and experimental groups $(n=50)$

\begin{tabular}{lccc}
\hline \multirow{2}{*}{ Ingredients } & \multicolumn{3}{c}{ Broiler chickens 14-28 days old, $\mathrm{n}=50$} \\
\cline { 2 - 4 } & Control group & I experimental group with Mn-pantothenate & II experimental group with Mn-lysine \\
\hline Inorganic Mn (with feed, basic diet), $\mathrm{mg}$ & 115 & 90 & 90 \\
Mn-pantothenate (with water), $\mathrm{mL}$ & 0.0 & 0.2 & 0.0 \\
Mn-lysine (with water), $\mathrm{mL}$ & 0.0 & 0.0 & 0.5 \\
\hline
\end{tabular}

\section{Table 2}

Composition and nutritional value of standard feed for broiler chickens of control and experimental groups

\begin{tabular}{|c|c|c|c|}
\hline Characteristics & Starter, 11-21 days & Grower, $22-35$ days & Finisher, $36-45$ days \\
\hline Corn, $\mathrm{g} / \mathrm{kg}$ & 400 & 400 & 420 \\
\hline Sunflower meal, $g / k g$ ( $33 \%$ of raw protein) & 60 & 58 & 90 \\
\hline Wheat, g/kg & 176.2 & 193.4 & 190.2 \\
\hline Soy full fat extruded, $g / k g$ ( $34 \%$ of raw protein) & 88.0 & 168.6 & 184.0 \\
\hline Soybean meal, $\mathrm{g} / \mathrm{kg}(41 \%$ of raw protein) & 225.8 & 130.0 & 65.8 \\
\hline Premix, g/kg & 50 & 50 & 50 \\
\hline \multicolumn{4}{|c|}{ Nutrition (counted) } \\
\hline Exchange energy, kcal/100 g & 311 & 318 & 319 \\
\hline Raw protein, $\%$ & 19.6 & 18.6 & 17.5 \\
\hline Calcium, $\%$ & 0.84 & 0.76 & 0.77 \\
\hline Available phosphorus, $\%$ & 0.42 & 0.38 & 0.38 \\
\hline \multicolumn{4}{|c|}{ Trace elements (defined) } \\
\hline Zinc, mg/kg & 100 & 100 & 100 \\
\hline Manganese, mg/kg & 90 & 90 & 90 \\
\hline
\end{tabular}

A clinical study and weighing of the birds of the control and experimental groups were carried out before the blood samples were taken on the 14th, 21st, and 28th days of rearing. The severity of symptoms in broiler chickens was determined using diagnostic criteria for perosis assessment: I degree - slightly displaced calf tendons; II degree - displaced calf tendons and III degree - displaced calf tendons, enlarged hocks, and twisted legs.

From each group of chickens, 20 birds were randomly selected for blood sampling and subsequent analysis. Blood samples for the study were taken by the intravital puncture method from the axillary vein, $2.5 \mathrm{~mL}$ from each bird (Kelly et al., 2013; Sakara et al., 2018), into Vacutainer tubes (Becton Dickinson, England) with a blood coagulation activator and gel. Then the tubes with blood samples were kept for 30 minutes at room temperature, until the clot compartment. The samples were centrifuged at $3000 \mathrm{rpm}$ for $10 \mathrm{~min}$ until the final separation of the serum from the blood cells.

The concentration determination of total protein, albumin, total calcium, inorganic phosphorus, magnesium, was carried out according to the manufacturer's instructions, using "Filisit-diagnostics" reagents (Filisitdiagnostics, Ukraine) with the Stat Fax 1904+ biochemical analyser (Awareness Technology, USA). The study of the manganese and zinc content in the poultry blood serum was carried out by atomic absorption spectrophotometry using the Shimadzu AA-6650 device with an electro- thermal atomizer (Shimadzu Corporation, Kyoto, Japan). Dilution of standards and serum was carried out according to the recommendations for the device using (Shimadzu Corporation. Atomic absorption spectrophotometry cookbook. Section 1: Basic Conditions of Analysis of Atomic Absorption Spectrophotometry).

The content of microelements ( $\mathrm{Zn}, \mathrm{Mn})$ was investigated in compound feeds for all periods of feeding (pre-starter, starter, grower, finisher) at the Laboratory of Toxicological Monitoring of the Department of Toxicology, Safety and Quality of Agricultural Products of the National Research Centre "Institute of Experimental and Clinical Veterinary Medicine" using the method of X-ray fluorescence analysis following the manuals for the device Spectroscan-Max (Spectron, Russian Federation).

The results were determined as mean \pm standard error $(x \pm S E)$. A Bonferroni-corrected ANOVA was used to determine the difference between the samples. The results were considered reliable at $\mathrm{P}<0.05$. The results of the studies were statistically calculated using the Statistica 10 program (StatSoft Inc., USA, 2011).

\section{Results}

It was found that in birds of all groups at the age of 14 days old (beginning of the study), visible mucous membranes were a pale pink colour, disorientation, and fragility with a disproportionate plumage growth were 
observed. In all three groups, no chickens with perosis were found. At the end of the experiment, 28 day old chickens from two experimental groups were active, willingly ate feed, and consumed water, the plumage of the birds was tightly attached to the body. It should also be noted that there were no chickens with perosis found among those that had consumed manganese pantothenate and lysinate with water. In the birds of the control group, pronounced dishevelled plumage, pallor of mucous membranes, growth retardation, and diarrhea were noted. Perosis developed in 4 chickens of the control group ( $8 \%$ ), with the second stage of legs' damage.

According to the weighing results, it was found that after 7 days of drinking manganese pantothenate and lysinate, the average body weight

\section{Table 3}

Dynamics of weight gain in broiler chickens of control and experimental groups $(x \pm S E, n=50)$

\begin{tabular}{|c|c|c|c|}
\hline \multirow{2}{*}{ Group } & \multicolumn{3}{|c|}{ Age of broiler chickens } \\
\hline & 14th days & 21st days & 28th days \\
\hline Control & $400.7 \pm 17.6$ & $704.8 \pm 22.9^{\circ 00}$ & $1075.5 \pm 34.5^{\circ 00}$ \\
\hline Iexperimental group with Mn-pantothenate & $406.4 \pm 14.5$ & $772.3 \pm 24.8^{* \infty 00}$ & $1209.1 \pm 28.4^{* * *} \circ \circ \circ$ \\
\hline II experimental group with $\mathrm{Mn}$-lysine & $392.3 \pm 23.2$ & $777.6 \pm 24.9 * * \circ \circ$ & $1217.7 \pm 33.6^{* * * \circ \circ \circ \circ}$ \\
\hline
\end{tabular}

Note: ${ }^{*}-\mathrm{P}<0.05,{ }^{* *}-\mathrm{P}<0.01,{ }^{* * *}-\mathrm{P}<0.001$ compared to control; ${ }^{\circ}{ }^{\circ}-\mathrm{P}<0.001$ compared to the beginning of the experiment.

Table 4

Blood biochemical parameters in broiler chickens of control and experimental groups $(x \pm S E, n=20)$

\begin{tabular}{|c|c|c|c|c|}
\hline \multirow{2}{*}{ Indicator } & \multirow{2}{*}{ Groups } & \multicolumn{3}{|c|}{ Age of broiler chickens } \\
\hline & & 14th days & 21st days & 28th days \\
\hline \multirow{3}{*}{$\begin{array}{l}\text { Total protein, } \\
\mathrm{g} / \mathrm{L}\end{array}$} & Control & $29.5 \pm 0.7$ & $29.0 \pm 1.0$ & $30.6 \pm 0.6$ \\
\hline & I experimental group with Mn-pantothenate & $30.0 \pm 0.4$ & $30.4 \pm 0.8$ & $34.4 \pm 0.7^{000} * * *$ \\
\hline & II experimental group with $\mathrm{Mn}$-lysine & $30.6 \pm 0.6$ & $31.8 \pm 0.5^{* *}$ & $35.1 \pm 0.9^{\circ 00 * * *}$ \\
\hline \multirow{3}{*}{$\begin{array}{l}\text { Albumin, } \\
\mathrm{g} / \mathrm{L}\end{array}$} & Control & $16.6 \pm 0.78$ & $16.3 \pm 0.3$ & $16.8 \pm 0.6$ \\
\hline & I experimental group with Mn-pantothenate & $17.2 \pm 0.9$ & $18.0 \pm 0.3$ & $18.7 \pm 1.0^{*}$ \\
\hline & II experimental group with $\mathrm{Mn}$-lysine & $16.6 \pm 0.4$ & $17.4 \pm 0.4$ & $18.3 \pm 0.4 * \infty \circ \circ$ \\
\hline \multirow{3}{*}{$\begin{array}{l}\text { Magnesium, } \\
\mathrm{mmol} / \mathrm{L}\end{array}$} & Control & $0.96 \pm 0.04$ & $0.95 \pm 0.02$ & $0.91 \pm 0.04$ \\
\hline & I experimental group with Mn-pantothenate & $0.87 \pm 0.03$ & $0.98 \pm 0.02^{\circ \circ}$ & $0.99 \pm 0.02 * \circ$ \\
\hline & II experimental group with $\mathrm{Mn}$-lysine & $0.88 \pm 0.05$ & $1.00 \pm 0.10^{* * \circ}$ & $1.00 \pm 0.10 * \circ$ \\
\hline \multirow{3}{*}{$\begin{array}{l}\text { Manganese, } \\
\mu \mathrm{mol} / \mathrm{L}\end{array}$} & Control & $1.9 \pm 0.1$ & $1.9 \pm 0.2$ & $1.9 \pm 0.1$ \\
\hline & I experimental group with Mn-pantothenate & $1.7 \pm 0.1$ & $2.1 \pm 0.1^{\circ \circ}$ & $2.7 \pm 0.3 * * \circ 00$ \\
\hline & II experimental group with Mn-lysine & $1.7 \pm 0.2$ & $2.0 \pm 0.2$ & $2.6 \pm 0.3 * * \infty$ \\
\hline \multirow{3}{*}{$\begin{array}{l}\text { Zinc, } \\
\mu \mathrm{mol} / \mathrm{L}\end{array}$} & Control & $25.4 \pm 1.2$ & $24.8 \pm 0.8$ & $25.2 \pm 1.4$ \\
\hline & I experimental group with Mn-pantothenate & $25.8 \pm 1.4$ & $28.7 \pm 1.1 * *$ & $27.8 \pm 1.1$ \\
\hline & II experimental group with Mn-lysine & $26.5 \pm 0.9$ & $27.1 \pm 1.3$ & $27.0 \pm 1.3$ \\
\hline
\end{tabular}

Note: *-P $<0.05,{ }^{* *}-\mathrm{P}<0.01,{ }^{* * *}-\mathrm{P}<0.001$ compared to control; ${ }^{\circ}-\mathrm{P}<0.05,{ }^{\circ}-\mathrm{P}<0.01,{ }^{\circ}{ }^{\circ}-\mathrm{P}<0.001$ compared to the beginning of the experiment.

It was found that after 14 days of manganese pantothenate and lysinate consumption, the level of albumin in the broiler chickens' blood serum had increased by $10.2 \%$ and $8.2 \%$, respectively, compared with the control indices $(\mathrm{P}<0.05)$. The concentration of magnesium in the broiler chickens' blood serum at the end of the study in the experimental groups, which received manganese pantothenate and lysinate, was $8.1 \%$ and $9.0 \%$ respectively higher than in birds of the control group $(\mathrm{P}<0.05$; Table 4$)$. The level of manganese in the blood serum of chickens after 14 days of this mineral pantothenate's application increased by $29.6 \%(\mathrm{P}<0.01$; Table 4) compared with the indicators of the control group. Also, significant changes were diagnosed by the additional drinking of manganese lysinate, after 14 days the concentration of this trace element in the blood serum of the experimental birds was $26.9 \%$ higher than in the control group $(\mathrm{P}<0.01)$. As for zinc, significant changes in its concentration in the broiler chickens' blood serum were recorded after 7 days of consumption of manganese pantothenate. Thus, the zinc content was $13.6 \%$ higher than in the blood serum of the control group birds $(\mathrm{P}<0.01)$.

\section{Discussion}

To increase the bioavailability of trace elements in industrial poultry feed, various forms of compounds are used: nanoparticles (Matuszewski et al., 2020), inulin prebiotics (Ahmad et al., 2021), chelates (Meng et al., 2021), and nanoaquachelates (Nguyen et al., 2019). Chelates are a special group of complex chemical compounds that have been known to researchers for more than eight decades. They are heterocyclic compounds in which a metal ion is bound to ligands (amino acids, peptides, etc.). The most stable complexes have the structure of five- and six-membered rings (Vieira, 2008; Stanaćev et al., 2014). In the research of Meng et al. of chickens in the experimental groups was greater than that of the control by $8.7 \%$ and $9.4 \%(\mathrm{P}<0.001$; Table 3$)$, respectively. At the end of experiment, on the 28th day of the chickens' life, the difference in body weight increased by $11.0 \%$ and $11.7 \%$, respectively $(\mathrm{P}<0.001)$.

We found that after 7 days of consumption of manganese lysinate, the total protein concentration in the chickens' blood serum was $8.8 \%$ higher than that of the birds in the control group $(\mathrm{P}<0.01$; Table 4). After 14 days of consumption of manganese pantothenate and lysinate, the total protein content was higher by $11.0 \%$ and $12.8 \%$ respectively, in comparison with the indicators of the control group, who received the standard diet $(\mathrm{P}<0.001)$ 
on both the chickens' organism and the environment in the future will increase (Zhu et al., 2019). Therefore, we did not consider this solution to the problem expedient. Sunder et al. (2006) have shown that the addition of organic manganese in the amount of $100 \mathrm{mg} / \mathrm{kg}$ of compound feed optimizes performance, mineralization, and immune response in broiler chickens. The use of organic sources of trace elements ( $\mathrm{Zn}, \mathrm{Mn}$, and Se) in broiler chickens' diets increases their concentration in the blood and liver, but without changes in the composition of bones compared to using their inorganic forms. Feed additives formulated with $50 \%$ organic and $50 \%$ inorganic minerals are giving similar results (Lopes et al., 2018).

The results of another study (Mwangi et al., 2019) confirmed that feeding broiler chickens with a slight deficiency of manganese in the diet affects the growth rate and the concentration of this element in tissues. The addition of 75-100 mg/kg manganese to the main corn-soy diet increases overall resistance and reduces the fat deposition in broiler chickens (Ghosh et al., 2016). This trace element in organic form has a higher efficiency than inorganic (Mn-sulfate), and the methionine ligand promotes the absorption of the manganese better than glycine (Olgun et al., 2017). The research results mentioned above are consistent with our findings in the current study. The serum manganese content of broilers that received manganese chelates was higher by $29.6 \%$ and $26.9 \%(\mathrm{P}<0.01)$, respectively, compared with the indices in chickens fed a standard diet containing only inorganic manganese.

The amino acid lysine, which is the part of a lysinate, improves protein assimilation (Chang et al., 2018). Therefore, it could contribute to an increase in the weight and the concentration of total protein in the chickens' serum by $12.8 \%(\mathrm{P}<0.001)$, after using the manganese lysinate in our experiment. Similar research results were obtained by (Yuan et al., 2015). The increase in the albumin concentration due to the addition of lysine to a feed for laying hens is described in his studies by (Shahir et al., 2006). The increase in total protein content by $11.0 \%$ after the use of manganese pantothenate, in our opinion, was due to the glycine content (Siegert et al., 2019). Glycine and pantothenic acid affected the increase in the body weight when pantothenate solidified. Wang et al. (2016) in his research described the effectiveness of the use of pantothenic acid in increasing body weight gain and optimizing metabolism in birds.

Khillare et al. (2019) indicated in their research that introducing manganese glycinate into broiler chickens' diets helps to balance the concentration of metals in the blood. Thus, the blood serum indices of the poultry of the experimental groups in our studies demonstrated an increase in the concentration of magnesium by $8.1-9.0 \%(\mathrm{P}<0.05)$ at the end of the experiment. Talking about an upward trend of the zinc concentration in the blood serum of birds who received the manganese pantothenate similar results were obtained by (Sunder et al., 2013). They found that the addition of organic manganese $60 \mathrm{mg} / \mathrm{kg}$ to a feed significantly increases the absorption of zinc $(\mathrm{P}<0.01)$.

\section{Conclusions}

The use of manganese chelates in the form of pantothenate $(0.2 \mathrm{~mL} / \mathrm{L}$ of water) and lysinate $(0.5 \mathrm{~mL} / \mathrm{L})$ during 14-28th days of broiler chicken rearing not only provides $100 \%$ prevention of perosis but also contributes to the body weight gain of birds by $11.0 \%$ and $11.7 \%(\mathrm{P}<0.001)$, respectively. The use of manganese pantothenate and lysinate in the recommended doses increases the concentration of total protein in the blood serum by $11.0 \%$ and $12.8 \%(\mathrm{P}<0.001)$, albumin by $10.1 \%$ and $8.2 \%(\mathrm{P}<0.05)$, magnesium by $8.1 \%$ and $9.0 \%(\mathrm{P}<0.05)$ and manganese by $29.6 \%$ and $26.9 \%(\mathrm{P}<0.01)$, respectively, compared with the indices in chickens fed a standard diet containing only inorganic manganese.

\section{The authors declare the absence of any conflict of interest.}

The current studies are at the initiative of the authors and do not have any outside financial support.

The authors are grateful to the Private enterprise "Kronos-Agro" for the opportunity to use the manganese pantothenate and lysinate for research.

\section{References}

Ahmad, A. M., Ahmed, W., Iqbal, S., Javed, M., Rashid, S., \& Iahtisham-ul-Haq (2021). Prebiotics and iron bioavailability? Unveiling the hidden association - a review. Trends in Food Science and Technology, 110, 584-590.

Aschner, J. L., \& Aschner, M. (2005). Nutritional aspects of manganese homeostasis. Molecular Aspects of Medicine, 26, 353-362.

Bomko, V., Kropyvka, Y., Bomko, L., Chemyuk, S., Kropyvka, S., \& Gutyj, B. (2018). Effect of mixed ligand complexes of zinc, manganese, and cobalt on the manganese balance in high-yielding cows during first 100-days lactation. Ukrainian Journal of Ecology, 8(1), 420-425.

Britanico, E. B., Merca F. E., Angeles, A. A., Acda, S. P., \& Luis, E. S. (2012). Effects of supplementing diets with amino acid chelates of copper, zinc, manganese and iron on the performance of broilers. Philippine Journal of Veterinary and Animal Sciences, 38(1), 1-10.

Chang, L., Xie, P., Bu, Z., Wang, Q., Fu, S., \& Mu, C. (2018). Effect of dietary lysine level on performance, egg quality and serum biochemical indices of laying pigeons. Journal of Applied Poultry Research, 27(2), 152-158.

Dinev, I. (2012). Leg weakness pathology in broiler chickens. The Joumal of Poultry Science, 49, 63-67.

Gajula, S. S., Chelasani, V. K., Panda, A. K., Mantena, V. L., \& Savaram, R. R. (2011). Effect of supplemental inorganic $\mathrm{Zn}$ and $\mathrm{Mn}$ and their interactions on the performance of broiler chicken, mineral bioavailability, and immune response. Biological Trace Element Research, 139, 177-187.

Ghosh, A., Mandal, G. P., Roy, A., \& Patra, A. K. (2016). Effects of supplementation of manganese with or without phytase on growth performance, carcass traits, muscle and tibia composition, and immunity in broiler chickens. Livestock Science, 191, 80-85.

Ji, F., Luo, X., Lu, L., Liu, B., \& Yu, S. (2006). Effect of manganese source on manganese absorption by the intestine of broilers. Poultry Science, 85(11), 19471952.

Kelly, L. M., \& Alworth, L. C. (2013). Techniques for collecting blood from the domestic chicken. Lab Animal, 42, 359-361.

Khakpour, I. F., Janmohammadi, H., Kianfar, R., \& Sahraei, M. (2019). Evaluation of chemical characteristics and effects of different manganese sources on kinetics of manganese absorption and performance of broiler chickens. Iranian Journal of Applied Animal Science, 9(3), 463-471.

Khillare, G., Shyamkumar, T., Ahmad, M., Prabhakar, G., Rokade, J., Beulah, P., Kolluri, G., Mohan, J., \& Gopi, M. (2019). Effects of dietary manganese supplementation on selected biochemical characteristics and minerals in broiler breeder seminal plasma. Indian Journal of Poultry Science, 54(1), 37.

Knowles, T. G., Kestin, S. C., Haslam, S. M., Brown, S. N., Green, L. E., Butterworth, A., Pope, S., Pfeiffer, D., \& Nicol, C. J. (2008). Leg disorders in broiler chickens: Prevalence, risk factors and prevention. PLoS One, 3(2), e1545.

Li, S. F, Luo, X., Lu, L., Liu, B., Kuang, X., Shao, G., \& Yu, S. (2008). Effect of intravenously injected manganese on the gene expression of manganese-containing superoxide dismutase in broilers. Poultry Science, 87(11), 2259-2265.

Lilburn, M. S. (2021). Centennial review: Trace mineral research with an emphasis on manganese: Dedicated to Dr. Roland M. Leach, jr. Poultry Science, 2021, 101222.

Liu, R., Jin, C., Wang, Z., Wang, Z., Wang, J., \& Wang, L. (2015). Effects of manganese deficiency on the microstructure of proximal tibia and OPG/RANKL gene expression in chicks. Veterinary Research Communications, 39(1), 31-37.

Lopes, M., Paroul, N., Barbosa, J., Valduga, E., Cansian, R. L., Toniazzo, G., \& Oliveira, D. (2018). Effect of partial and total replacement of inorganic by organic microminerals sources on the quality of broiler carcasses. Brazilian Archives of Biology and Technology, 60, 1-11.

Matuszewski, A., Łukasiewicz, M., Łozicki, A., Niemiec, J., Zielińska-Górska, M., Scott, A., Chwalibog, A., \& Sawosz, E. (2020). The effect of manganese oxide nanoparticles on chicken growth and manganese content in excreta. Animal Feed Science and Technology, 268, 114597.

Maynard, C., Ghane, A., Chrystal, P., Selle, P., \& Liu, S. (2021). Sustaining live performance in broilers offered reduced crude protein diets based on com and wheat blend. Animal Feed Science and Technology, 276, 114928.

Meng, T., Gao, L., Xie, C., Xiang, Y., Huang, Y., Zhang, Y., \& Wu, X. (2021). Manganese methionine hydroxy analog chelated affects growth performance, trace element deposition and expression of related transporters of broilers. Animal Nutrition, 2021, in press.

Mwangi, S., Timmons, J., Ao, T., Paul, M., Macalintal, L., Pescatore, A., Cantor, A., \& Dawson, K. (2019). Effect of manganese preconditioning and replacing inorganic manganese with organic manganese on performance of male broiler chicks. Poultry Science, 98(5), 2105-2113.

Nguyen, M. K., Moon, J., Bui, V. K., Oh, Y., \& Lee, Y. (2019). Recent advanced applications of nanomaterials in microalgae biorefinery. Algal Research, 41, 101522.

Noetzold, T., Vieira, S., Favero, A., Hom, R., Silva, C., \& Martins, G. (2020). Manganese requirements of broiler breeder hens. Poultry Science, 99(11), 5814-5826. 
Nollet, L., Huyghebaert, G., \& Spring, P. (2008). Effect of different levels of dietary organic (bioplex) trace minerals on live performance of broiler chickens by growth phases. Joumal of Applied Poultry Research, 17, 109-115.

Olgun, O. (2017). Manganese in poultry nutrition and its effect on performance and eggshell quality. World's Poultry Science Joumal, 73, 45-56.

Oviedo-Rondón, E. O., Ferket, P. R., \& Havestein, G. B. (2006). Nutritional factors that affect leg problems in broilers and turkeys. Avian and Poultry Biology Reviews, 17, 89-103.

Pacheco, B., Nakagi, V., Kobashigawa, E., Caniatto, A., Faria, D., \& Faria Filho, D. (2017). Dietary levels of zinc and manganese on the performance of broilers between 1 to 42 days of age. Revista Brasileira de Ciência Avícola, 19(2), 171-178.

Ramos-Vidales, D., Ramos-Vidales, D., Gómez-Verduzco, G., Cortes-Cuevas, A. Del Río-García, J. C., Fernández-Tinoco, S., Chárraga-Aguilar, S., \& ÁvilaGonzález, E. (2019). Organic trace minerals on productive performance, egg quality and immune response in Bovans White laying hens. Journal of Animal Physiology and Animal Nutrition, 103(5), 1484-1491.

Richards, J. D., Zhao, J., Harrell, R. J., Atwell, C. A., \& Dibner, J. J. (2010). Trace mineral nutrition in poultry and swine. Asian-Australasian Journal of Animal Sciences, 23(11), 1527-1534.

Sakara, V., Melnyk, A., \& Moskalenko, P. (2018). Osoblivosti vidbonu krovi u kurchat-brojleriv riznogo viku [Features of blood selection in kurchat broilers of different age]. Scientific Bulletin of Veterinary Medicine, 2, 60-65 (in Ukrainian).

Saldanha, M. M., Araújo, I. C., Triguineli, M. V., Vaz, D. P., Ferreira, F. N., Albergaria, J. D., Fontes, D. O., \& Lara, L. J. (2020). Relative bioavailability of manganese in relation to proteinate and sulfate sources for broiler chickens from one to 20 D of age. Poultry Science, 99(11), 5647-5652.

Santiago, G., Vieira, S., Stefanello, C., Simões, C., Kindlein, L., Maria, D., \& Ibairro, P. (2020). Dietary choline affects field performance and broiler leg deviations. Livestock Science, 240, 104127.

Shahir, M. H., Shariatmadari, F., Mirhadi, S. A., \& Chwalibog, A. (2006). Determination of lysine requirement of laying hen using serum biochemical indicators. Archiv fur Geflugelkunde, 70(2), 74-79.

Siegert, W., \& Rodehutscord, M. (2019). The relevance of glycine and serine in poultry nutrition: A review. British Poultry Science, 60, 579-588.

Stanaćev, V. S., Milošević, N., Stanaćev, V., Puvača, N., Milić, D., \& Pavlovski, Z. (2014). Chelating forms of microelements in poultry nutrition. World's Poultry Science Joumal, 70, 105-112.
Sunder, G. S., Kumar, C. V., Panda, A., Raju, M., \& Rao, S. R. (2013). Effect of supplemental organic $\mathrm{Zn}$ and $\mathrm{Mn}$ on broiler performance, bone measures, tissue mineral uptake and immune response at 35 days of age. Current Research in Poultry Science, $3,1-11$.

Sunder, G. S., Panda, A. K., Gopinath, N. C., Raju, M. V., Rao, S. V., \& Kumar, C. V. (2006). Effect of supplemental manganese on mineral uptake by tissues and immune response in broiler chickens. The Journal of Poultry Science, 43, 371-377.

Tufarelli, V., \& Laudadio, V. (2017). Manganese and its role in poultry nutrition: An overview. Journal of Experimental Biology and Agricultural Sciences, 5, 749-754.

Umar Yaqoob, M., Wang, G., Sun, W., Pei, X., Liu, L., Tao, W., Xiao, Z., Wang, M., Huai, M., Li, L., \& Pelletier, W. (2020). Effects of inorganic trace minerals replaced by complexed glycinates on reproductive performance, blood profiles, and antioxidant status in broiler breeders. Poultry Science, 99(5), 2718-2726.

Vieira, S. (2008). Chelated minerals for poultry. Revista Brasileira de Ciência Avícola, 10, 73-79.

Wang, B., Zhang, X., Yue, B., Ge, W., Zhang, M., Ma, C., \& Kong, M. (2016). Effects of pantothenic acid on growth performance, slaughter performance, lipid metabolism, and antioxidant function of Wulong geese aged one to four weeks. Animal Nutrition, 2, 312-317.

Wang, H., Gao, W., Huang, L., Shen, J., Liu, Y., Mo, C., Yang, L., \& Zhu, Y. (2020). Mineral requirements in ducks: An update. Poultry Science, 99(12), 6764-6773.

Yuan, Y., Zhao, X., Zhu, Q., Li, J., Yin, H., Gilbert, E. R., Zhang, Y., Liu, Y., Wang, Y., Li, D., Yang, Z., \& Shu, G. (2015). Effects of dietary lysine levels on carcass performance and biochemical characteristics of chinese local broilers. Italian Journal of Animal Science, 14,3840.

Zhang, Y., Wang, S., Huang, X., Li, K., Chen, W., Ruan, D., Xia, W., Wang, S., Abouelezz, K., \& Zheng, C. (2020). Estimation of dietary manganese requirement for laying duck breeders: Effects on productive and reproductive performance, egg quality, tibial characteristics, and serum biochemical and antioxidant indices. Poultry Science, 99(11), 5752-5762.

Zhu, Z., Yan, L., Hu, S., An, S., Lv, Z., Wang, Z., Wu, Y., Zhu, Y., Zhao, M., Gu, C., \& Zhang, A. (2019). Effects of the different levels of dietary trace elements from organic or inorganic sources on growth performance, carcass traits, meat quality, and faecal mineral excretion of broilers. Archives of Animal Nutrition, $73,324-337$ 